\title{
A revision of the Devonian Malvinokaffric dalmanitid trilobite Dalmanitoides Delo, 1935, on the basis of new data from Argentina
}

\author{
Juan J. Rustán and N. Emilio Vaccari
}

\begin{abstract}
In light of new information on holotypes and additional material from the Lower Devonian type areas from Argentina, the dalmanitid trilobite Dalmanitoides Delo, 1935, is rediagnosed and considered a dalmanitine rather than a synphoriine. Comparisons suggest that Gamonedaspis Braniša and Vaněk, 1973, is a junior synonym of Dalmanitoides, so that this Early-Middle Devonian genus includes at least five species: four formally named from South America, D. drevermanni (Delo, 1935), D. boehmi (Knod, 1908), D. scutata (Braniša and Vaněk, 1973), and D. accola (Clarke, 1913), together with a species from South Africa herein treated in open nomenclature (D. $\mathrm{sp}$. A). Although the number of Dalmanitoides species suggests a diversification of cosmopolitan dalmanitines already present in Malvinokaffric basins, a close relationship with the boreal and slightly older Roncellia Lespérance and Bourque, 1971, would suggest migration from the Eastern Americas Paleobiogeographical Realm during the Early Devonian as origin of the clade, which is in accordance with paleobiogeographic patterns recognized on the basis of evidence from synphoriine distributions.
\end{abstract}

Juan José Rustán. CIPAL - CICTERRA (Facultad de Ciencias Exactas Físicas y Naturales, Universidad Nacional de Córdoba - CONICET), Av. Vélez Sársfield 299, 5000, Córdoba, Argentina

and

Museo de Ciencias Naturales, Universidad Nacional de La Rioja, Av. René Favaloro s/n 5300- La Rioja, Argentina, juanjorustan@gmail.com

N. Emilio Vaccari. CIPAL - CICTERRA (Facultad de Ciencias Exactas Físicas y Naturales, Universidad Nacional de Córdoba - CONICET), Av. Vélez Sársfield 299, 5000, Córdoba, Argentina

and

Museo de Ciencias Naturales, Universidad Nacional de La Rioja, Av. René Favaloro s/n 5300- La Rioja, Argentina, evaccari@efn.uncor.edu

KEYWORDS: dalmanitid trilobites; Devonian; Argentina; Malvinokaffric; Dalmanitoides; Gamonedaspis; systematics; paleobiogeography 

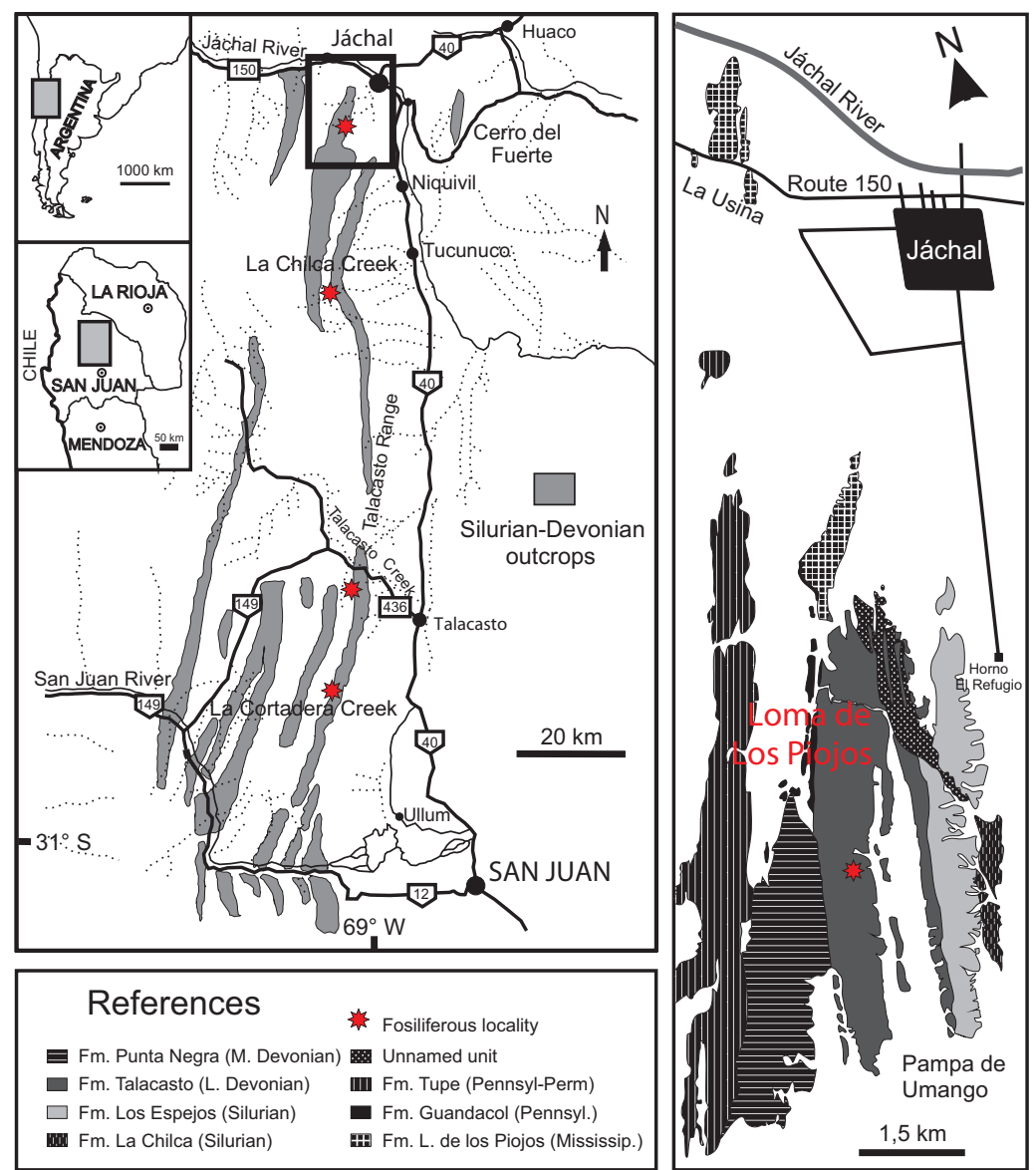

FIGURE 1. Left: location map of the Central Argentine Precordillera basin, San Juan Province, western Argentina, showing Silurian-Devonian outcrops and fossiliferous localities. Right: the type area of Dalmanitoides drevermanni and $D$. boehmi at the Loma de los Piojos locality, to the southwest of Jáchal, shown in more detail.

\section{INTRODUCTION}

Pioneering geological and paleontological surveys were carried out in western Argentina during the 19th and early 20th centuries. As a result of these works, two new dalmanitid trilobite species were recognized in the Lower Devonian sedimentary succession known as the Talacasto Formation (Figure 1) that crops out a few kilometers to the southwest of Jáchal, San Juan Province. Subsequently cited as "Cerro del Agua Negra," "Agua de Felipe," or "west of Jáchal Valley," the present-day name for these localities corresponds to the neighborhood of the Loma de los Piojos locality (Figure 1).

Dalmanitoides drevermanni (Thomas, 1906), was erected on the basis of a single specimen composed of a cephalon, pygidium and a few fragmentary thoracic segments associated in a single carbonate nodule. This holotype (housed in Germany) is from an undetermined stratigraphic level and was poorly illustrated. No more specimens were collected, nor were further details on its occurrence provided, except in a recent brief treatment of the type specimen by Holloway and Carvalho (2009).

Dalmanitoides boehmi (Knod, 1908) is based on a nearly complete and outstretched articulated specimen preserved in a sandstone slab collected originally by Hauthal. This specimen was never illustrated photographically and until now, it lacked a diagnosis, detailed description, precise stratigraphic occurrence data, and repository information. Although this taxon was subsequently cited from Bolivia (Kozłowski, 1923) and South Africa (Cooper, 1982), its original provenance from western Argentina was overlooked (Cooper, 1982, p.61).

Apart from discussions on Gamonedaspis (Edgecombe, 1993), both species have been of interest in discussing several other closely related dalmanitid taxa such as Amazonaspis (Carvalho and Fonseca, 2007) and Fenestraspis (Holloway and Carvalho, 2009). However, the lack of suffi- 
cient material, revised diagnosis, and exhaustive descriptions, has precluded a reappraisal of their systematic, phylogenetic, and paleobiogeographic significance.

In this contribution, we report several additional specimens of both taxa coming from Loma de los Piojos and from some other localities of the Precordillera Basin of San Juan Province; as well as repository information of the holotype of $D$. boe$h m i$. On the basis of this new material, with stratigraphic and geographic data, a complete description is provided for each species, and the diagnoses are emended to allow better systematic comparisons and to provide new insights on the biostratigraphic rank of the taxa. The new information sheds light on the systematic, phylogenetic, and paleobiogeographic proposals discussed for related Malvinokaffric Devonian trilobites.

\section{GEOLOGICAL SETTING}

Aspects of the geologic setting relevant here have been adequately treated in several previous works (Baldis, 1975; Astini, 1991; Herrera, 1993, 1995a, 1995b; Edgecombe et al., 1994; Vaccari et al., 1994 ; Waisfeld et al., 1994; Bustos, 1996; Herrera and Bustos, 2001; Rustán and Vaccari, 2010). Fossils studied come from the Talacasto Formation (Padula et al., 1967), which is extensively exposed in the Central Argentine Precordillera of San Juan Province, western Argentina (Figure 1). This Lower Devonian unit is composed of a marine succession of intensely bioturbated greenish-gray mudstones with intercalated beds of sandstone. It starts with dark muddy levels basally, passing upwards into sandy levels with fossiliferous nodules (Figure 2). The Talacasto Formation reaches a maximum thickness of more than $1000 \mathrm{~m}$ in the northern part of the basin. It represents a muddy shelf depositional system developed during a highstand, and overlies the (mainly) Silurian shelf sequence of the Los Espejos Formation (Astini, 1991). The stratigraphic record of the Silurian-Devonian boundary in Central Precordillera is poor due to the presence of a discontinuity between Los Espejos and Talacasto Formations. The turbiditic system of the upper Lower-lower Upper Devonian Punta Negra Formation (Bracaccini, 1949) overlies the Talacasto Formation (Bustos, 1996; Bustos and Astini, 1997). According to the studies of the brachiopod fauna (Herrera, 1993, Racheboeuf and Herrera, 1994, Herrera and Bustos, 2001) the Talacasto Formation spans the early Lochkovian-Emsian. The top of the unit is considered diachronous, with late Pragian to earliest Emsian levels recorded in the

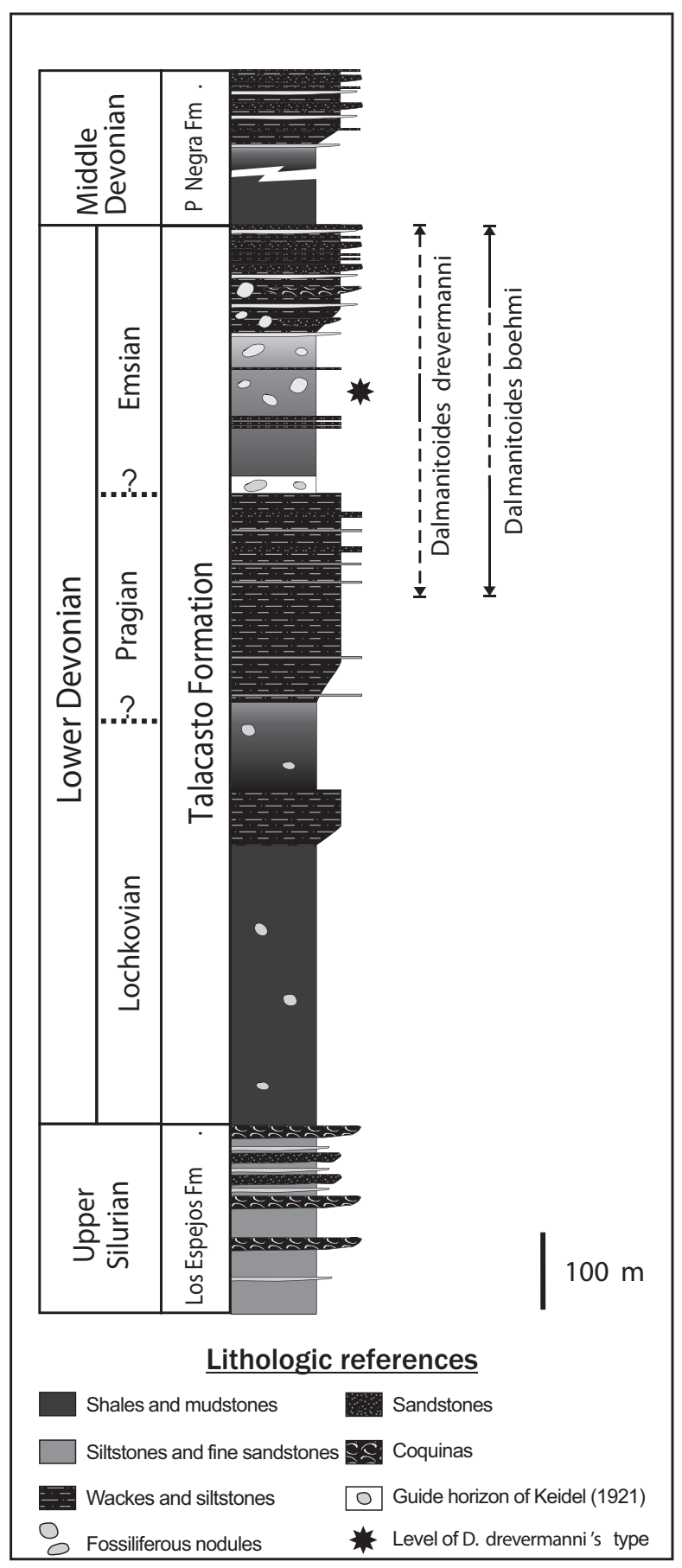

FIGURE 2. Stratigraphic column of the Talacasto Formation at Loma de los Piojos section, where it is most developed. Column shows the stratigraphic position of the studied Dalmanitoides species in Devonian sedimentary succession. Dashed lines represent low abundance, complete lines correspond to most fossiliferous levels. Star shows probable location of type levels of Dalmanitoides drevermanni. 
southern sections and younger late Emsian levels found in the northernmost sections. This can be recognized in the field, thanks to a distinctive latest Pragian to earliest Emsian stratigraphic light marker horizon, observed initially by Keidel (1921) and then by Astini (1991), which is continuous for more than $100 \mathrm{~km}$, from the Talacasto Creek (Herrera and Bustos, 2001, p. 369) to the Loma de los Piojos section to the north. The strata overlying this guide horizon, which are mainly recorded in the thicker northernmost sections of the basin, are overall considered of Emsian age.

\section{MATERIALS}

Devonian materials studied herein derive from classical sections of the Talacasto Formation, in San Juan Province, as follows (Figure 1): Talacasto Creek, the type section, that runs in an E-SW trend $60 \mathrm{~km} \mathrm{N-NW}$ of San Juan city; La Chilca Creek section, located approximately $16 \mathrm{~km}$ to the west of Tucunuco town; Loma de los Piojos section, located $7 \mathrm{~km}$ to the Southwest of Jáchal city (about $170 \mathrm{~km} \mathrm{N-NW}$ of San Juan city); and La Cortadera Creek, located $20 \mathrm{~km}$ to the Southwest of Talacasto, about $50 \mathrm{~km} \mathrm{N-NW}$ of San Juan city.

Illustrated specimens are housed in the paleontological repository of the Centro de Investigaciones Paleobiológicas (CIPAL), numbered with the prefix CEGH-UNC (Cátedra de Estratigrafía y Geología Histórica-Universidad Nacional de Córdoba), and in the collection of the Museo de Paleontología, numbered with the prefix CORD-PZ (Córdoba- Paleozoología) both belonging to the Universidad Nacional de Córdoba, Córdoba, Argentina.

Specimens of $D$. accola, were donated by J.C. White in 1906 to the New York State Museum, Albany, USA, housed there with the prefix NYSM.

The holotype of $D$. drevermanni is housed in Göttingen, Germany (Geowissenschaftliches Zentrum der Universität Göttingen, under repository number: GZG 15239).

The holotype of $D$. boehmi is housed in Freiburg, Germany (Institut für Geowissenschaften -Geologie, Albert-Ludwigs-Universität Freiburg, under repository number: 2778).

\section{SYSTEMATIC PALEONTOLOGY}

Superfamily DALMANITOIDEA Vogdes, 1890 Family DALMANITIDAE Vogdes, 1890

Subfamily DALMANITINAE Vogdes, 1890

Genus Dalmanitoides Delo, 1935
Type species. Dalmanites drevermanni Thomas, 1906

Emended diagnosis of the genus. Dalmanitine with short (sag., exsag.) anterior cephalic border, with short (sag.) and broad (tr.) anterior process; frontal glabellar lobe approximately rhombic in outline, bearing a delicate and narrow (tr.) depressed band of subtly more effaced ornamentation posteriorly located (sag.); glabella coarsely tuberculated; S3 broadening and shallowing at junction with axial furrow and anterior part of eye; S2 more convex forwards and apodemal adaxially, overall posterolaterally oriented and slightly concave forwards adaxially; S1 gently concave forwards, slightly posterolaterally directed and deepest adaxially; SO gently concave forwards, slightly posterolaterally directed; epiborder furrow on the lateral border continued along the external (lower) side of the genal spine; long and flattened genal spine; trend to develop some more swollen pygidial axial rings which variably exhibit either paired strong inflations, coarse tubercules or spines; delicate and narrow (tr.) sagittal band of effaced segmentation in the last several pygidial axial rings, progressively broader (tr.) backwards; pygidial pleural ribs strong and continuous, tending to be sinuous and to develop expansions and constrictions, and abruptly deflected backwards distally; posterior pygidial pleural bands bearing bulbous thickenings irregularly, which variably develop coarse tubercules or spines, the bases of which invade the following anterior pleural bands backwards; pygidial axis merging with a broad postaxial ridge passing into an upturned mucro.

Species included. $D$. drevermanni (Thomas, 1906), D. boehmi (Knod, 1908), D. accola (Clarke, 1913), D. scutata (Braniša and Vaněk, 1973), D. sp A (from South Africa, after Cooper, 1982).

Discussion. Gamonedaspis scutata Braniša and Vaněk, 1973, from the Pragian-Emsian of the Gamoneda Formation, Bolivia, is the type species of the genus Gamonedaspis. According to illustrations by Edgecombe (1993), this species shares with Dalmanitoides all of characters mentioned in the emended diagnosis of this latter genus above. Therefore we interpret Gamonedaspis as a junior synonym of the genus Dalmanitoides. The diagnosis of Dalmanitoides put forward by Delo (1935, p. 413) corresponds mainly to the type species $D$. drevermanni, so that it was extended to include Gamonedaspis species. 
This diagnosis comprises a unique character combination rather than an exhaustive list of generic apomorphies.

Species of Gamonedaspis were interpreted as dalmanitines by Edgecombe (1993), an opinion with which we agree. Meanwhile $D$. drevermanni, was originally considered a synphoriine (Delo, 1935), but was excluded from this subfamily by Lespérance and Bourque (1971, p. 186), although it was again regarded as a synphoriine by Holloway and Carvalho (2009, p. 940).

The recognition and definition of subfamilies within Dalmanitidae has been long discussed, and brief reviews of the literature (focused on Malvinokaffric dalmanitids), can be found in Carvalho and Fonseca (2007) and Holloway and Carvalho (2009). Herein, we follow considerations given by Campbell (1977) and Holloway (1981), together with additional taxonomic criteria drawn by Holloway and Carvalho (2009).

Besides previously available illustrations of $D$. drevermanni provided by Thomas (1906, plate 11, figure 1, 1a, 2, 2a, 3), and drawings based on them by Delo, 1935 (figures 28-29); systematic observations herein are based on new material collected in the type locality, together with high quality reillustrations of the holotype by Holloway and Carvalho (2009, figure $3 \mathrm{~A}-\mathrm{G}$ ).

Dalmanitoides drevermanni is now interpreted as a dalmanitine, based on the distance between $\mathrm{S} 1$ and $\mathrm{S} 2$ apodemes being less than 1.5 times the distance between SO and S1 apodemes; apodemal submesial part of S2 not equidimensional but transversely elongated; lateral border relatively broad (tr.) and bearing an epiborder furrow, nearly flat-topped and meeting the doublure in a sharp angle (Figure 3.10); dominating thoracic pleural furrow continued as a postfacetal furrow (Figure 4.3); pygidial pleural furrows tending to be lanceolate (Figure 5.4, 5.9) and gently asymmetrical in cross-section, with the posterior side more weakly inclined (Figure 5.15) (particularly when observed on internal moulds); posterior pleural bands subtly weaker than the anterior ones, fading towards the lateral border (Figure 5.4); and long and flattened genal spine exhibiting a continuation of the epiborder furrow (Figure 6.11).

Contrasting opinions on the subfamilial status of this species may be due to intraspecific variability together with a slightly different morphological expression of anatomical structures between internal and external moulds, observed for example between the exfoliated left side and the well-preserved right side of the holotype pygidium illus- trated by Holloway and Carvalho (2009, figure 3 $\mathrm{G})$; as well as in Figure 5 herein.

Dalmanitoides (specially D. drevermanni), closely resembles Fenestraspis amauta Braniša and Vaněk, 1973, as noted by Holloway and Carvalho (2009). Shared features include: median processes anteriorly; a short (sag., exsag.) cephalic border with small crenulations laterally; the pattern of coarse tubercles on the glabella; coarse tubercles or small spines on the thoracic axial rings; a convex projection of the most adaxial part of L2 invading forwards the apodemal area of S2; an elliptical expansion abaxially on S3 at the junction with the axial furrow and the anteriormost extremity of the palpebral lobe, accompanied by an abrupt shallowing; an effaced sagittal band of pygidial axial rings progressively broader (tr.) backwards; an upturned terminus; a broad postaxial ridge; and a similar distribution pattern of paired spines on some more inflated pygidial axial rings.

However, the intersegmental fenestrae, very tall eyes with a very different lens formula, a conspicuous palpebral rim, morphology and arrangement of glabellar lobes and furrows, almost straight morphology of pygidial pleural ribs, conspicuous indentations of the apodemal pits exsagitally along the pygidial axis, among many other differences with Dalmanitoides cited by Holloway and Carvalho (2009, p. 939-940), justify the generic separation of Fenestraspis.

So many similarities suggest a sister taxon relationship rather than a convergence between Dalmanitoides and Fenestraspis. Nevertheless, since Dalmanitoides (including Gamonedaspis) is reliably considered a dalmanitine, whereas Fenestraspis has most recently been interpreted as a synphoriine, our reasoning presents a major systematic problem: the subfamilial status of Fenestraspis. Certainly, Fenestraspis exhibits synphoriine characters i.e.: distance between S1 and S2 apodemes more than 1.5 times the distance between occipital and S1 apodemes; genal spine lacking a longitudinal furrow close to its lower edge, pleural bands of equal strength, the posterior one diminishing in height towards the border, and steep sided and symmetrical pygidial pleural furrow in cross section (Holloway and Carvalho, 2009).

These observations challenge the distinctiveness of subfamilies within dalmanitids, resurrecting an old and classic discussion (see Delo, 1935; Lespérance and Bourque, 1971; Lespérance, 1975; Campbell, 1977; Holloway, 1981; Carvalho and Fonseca, 2007; Holloway and Carvalho, 2009). Unraveling this major taxonomic issue requires an 


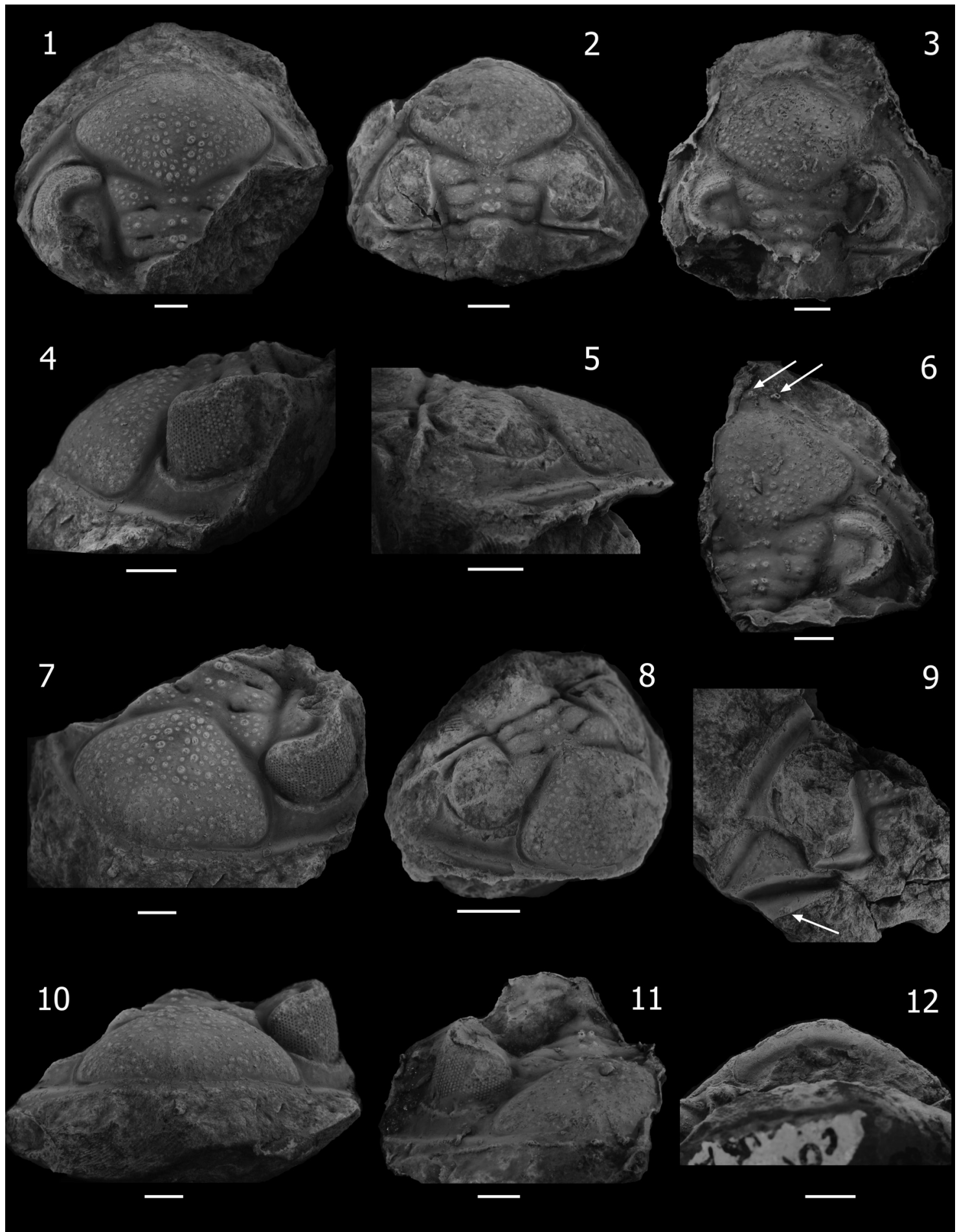

FIGURE 3. Cephala of Dalmanitoides drevermanni (Thomas, 1906). 1, 4, 6-7, 10-11 specimen CEGH-UNC 10499, partial cephalon: 1, internal mould dorsal view, 4, idem lateral view, 7, idem anterolateral dorsal view, 10, idem frontal view, 6, latex mould, dorsal view, arrows point to spiny processes on anterior border, 11, idem frontal view. 2-3, 5, 8, 12 specimen CORD-PZ 8615, partial cephalon: 2, internal mould, dorsal view, 5, idem lateral view, 8, idem anterolateral dorsal view, 12, detail of the anterior doublure and anterior margin, ventral view, 3, latex mould, dorsal view. 9 specimen CEGH-UNC 24304, partial cephalon, internal mould, dorsal view, arrow shows a spine on posterior border. Loma de los Piojos Section, Talacasto Formation, type early Emsian levels, San Juan Province, Argentina. Scale bar equals $5 \mathrm{~mm}$. 


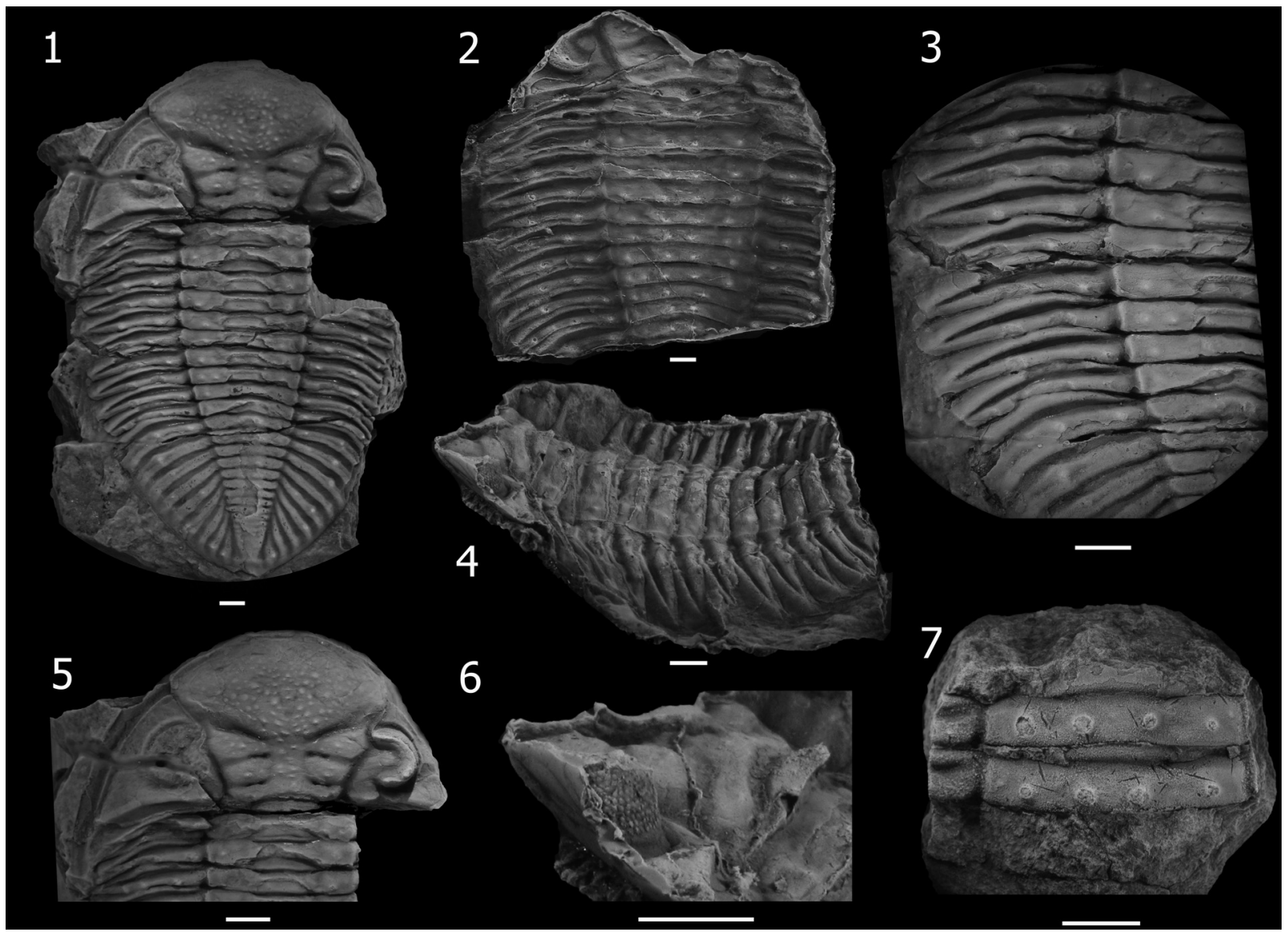

FIGURE 4. Articulated specimens of Dalmanitoides drevermanni (Thomas, 1906). 1-6, CEGH-UNC 12738, outstretched articulated specimen, strongly compressed dorso-ventrally: 1 , internal mould nearly complete, dorsal view, 2, latex cast, dorsal view, 3, detail of pleural lobes, internal mould, dorsal view, 4, latex cast, dorsolateral view, 5, detail of cephalon internal mould, dorsal view, 6, detail of occipital spine, dorsolateral view. Loma de los Piojos Section, Talacasto Formation, indeterminate levels, probably Pragian levels according to sandy lithology. 7, specimen CEGH-UNC 24309, two thoracic segments showing dorsal spine bases, type early Emsian levels, same section, San Juan Province, Argentina. Scale bar equals $5 \mathrm{~mm}$.

exhaustive revision of dalmanitids, which is beyond the aim of the present contribution, but which should be explored in future works.

Dalmanitoides exhibits a high intraspecific variability, and the overlapping wide range of morphologies complicate the recognition of species. Hence, most useful characters separating species of Dalmanitoides include: morphology of anterior cephalic margin, ornamentation of the occipital ring and posterior border, the proportional size and angle degree of the upturned mucro, and, although less clearly, pygidial ornamentation.

Dalmanitoides is considered to be closely related to Roncellia Lespérance and Bourque, 1971, from the Eastern Americas Paleobiogeographic Realm, mainly on the basis of pygidial characters, which was discussed at length by Edgecombe (1993).

\section{Dalmanitoides drevermanni (Thomas, 1906)}

Figures 3-6

Material. Loma de los Piojos: GZG 15239, CORDPZ 8098, 8608, 8610, 8615, CEGH-UNC 10499$10501,10503,10504,12738,24300-24310$, 24312-24314, 24316, Cerro La Chilca section 24318-24329 (tentatively).

Emended diagnosis. Dalmanitoides with paired anterior spiny projections medially and little spiny crenulations anterolaterally on anterior border, stout median spine on occipital ring and each thoracic axial ring with a couple of additional spines located laterally; small spines on the posterior border; glabella variably exhibiting paired large tubercles or spines on its median part; $16-18$ pygidial axial rings bearing paired spines most frequently on strongly swollen rings 1,3 and 4,7 or 8,12 and 


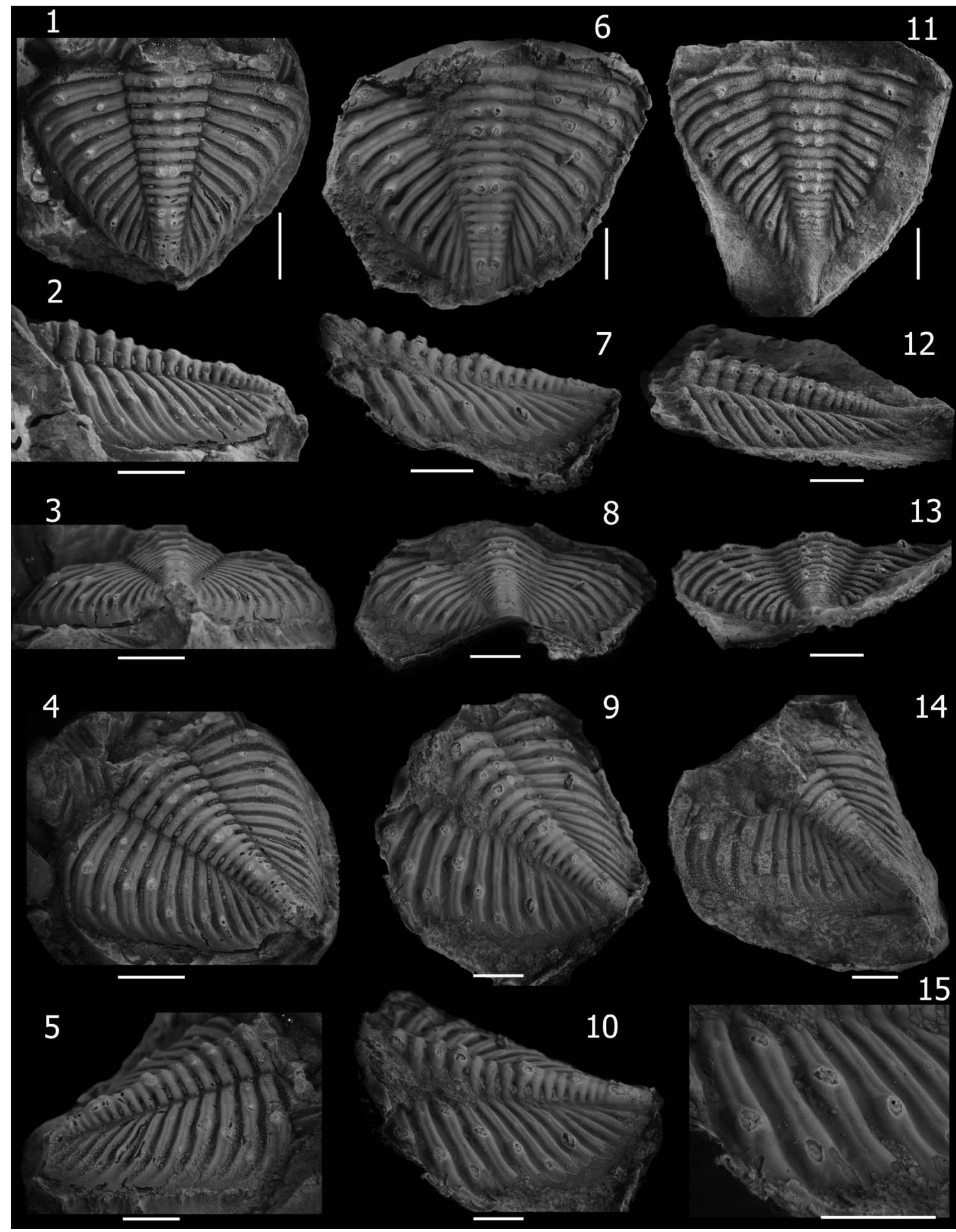

FIGURE 5. Pygidia of Dalmanitoides drevermanni (Thomas,1906). 1-5, specimen CEGH-UNC 24307, partial pygidium, internal mould: 1, dorsal view, 2, lateral view, 3, posterior view, 4, posterodorsolateral view, 5, dorsolateral view. 6-10, 15, specimen CORD-PZ 8608, partial pygidum latex cast, 6, dorsal view, 7, lateral view, 8, posterior view, 9, posterodorsolateral view, 10, dorsolateral view, 15 detail of pleural field. 11-13, specimen CEGH-UNC 24313, partial pygidium latex cast, 11, dorsal view, 12, lateral view, posterior view. 14, specimen CEGH-UNC 24302, partial pygidium, internal mould, posterodorsolateral view. Loma de los Piojos Section, Talacasto Formation, 11-13 Pragian levels, all remaining type early Emsian levels, San Juan Province, Argentina. Scale bar $=5 \mathrm{~mm}$. 


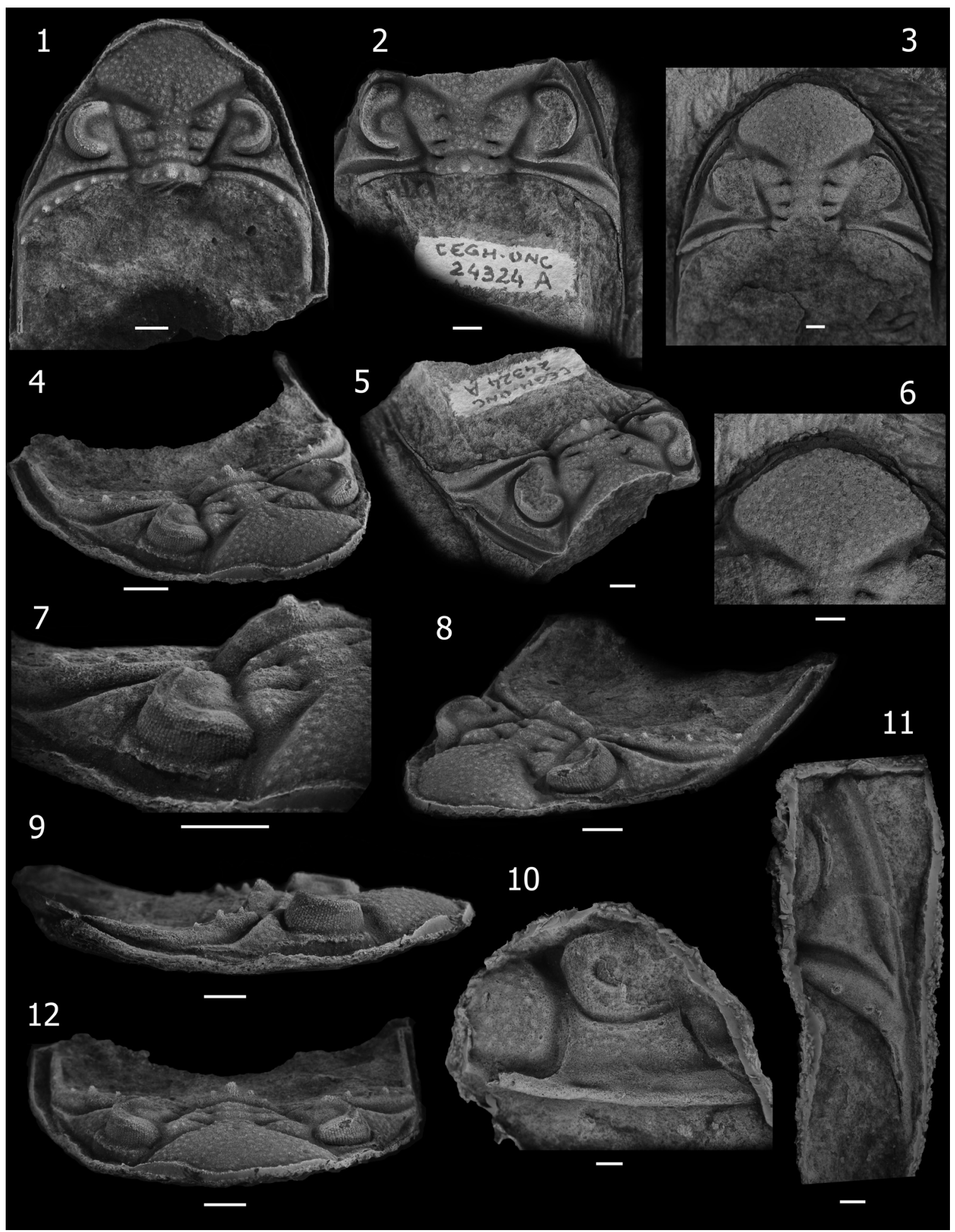

FIGURE 6. Cephala of Dalmanitoides drevermanni? (Thomas, 1906). 1, 3-4, 6-9, 12, specimen CEGH-UNC 24318, 1 , latex cast of partial cephalon, dorsal view, 3, internal mould, dorsal view, 4, latex cast, anterolateral view, 6, detail of anterior portion of cephalon, internal mould, 7, latex cast, anterolateral view, 8, anterolateral view, 9, lateral view, 12, frontal view. 2, 5, specimen CEGH-UNC 24324, partial cephalon: 2, dorsal view, 5, anterolateral view. 10, specimen CEGH-UNC 24327, latex cast of librigena, lateral view. 11, specimen CEGH-UNC 24324B, latex cast of a dalmanitine-type cheek showing a flat genal spine bearing a continuation of the epiborder furrow along its lower side. La Chilca section, Talacasto Formation, early Emsian levels, San Juan Province, Argentina. Scale bar equals 5 $\mathrm{mm}$. 
16; large spinose tubercles or spines on posterior pygidial pleural bands irregularly disposed but tending to define bilateral symmetry.

Description. Cephalon (Figure 3 ) widely subtriangular in outline, with length (sag.) about $55-60 \%$ of maximum width (tr.) at level of the occipital ring; anterolateral margins with successively diminishing little spiny crenulations or processes lateral to a median process, which bears two little anterolateral spiny projections. Anterior cephalic border approximately twice as long (sag., exsag.) medially as laterally (excluding processes), flattened to weakly concave, inclined outwards, slightly arched (convex) upwards in anterior view, in front of lateral part of frontal lobe and less arched upwards medially.

Glabella (excluding occipital ring) approximately as long (sag.) as wide (tr.). Axial furrow wide (tr.) and deep, nearly straight in front of L1 and L2, then bending outwards giving a maximum of lateral convexity in front of L3; deepest adjacent to L1, shallowing markedly adjacent to L3 and anteriormost part of L2, then increasing abruptly in depth (sloping downwards rapidly), along the posterolateral side of the frontal lobe until the anterolateral corner where it shallows and meets the lateral border furrow. Preglabellar furrow short (sag., exsag.) and shallow, slightly longer medially. LO (occipital ring) moderately long (sag., exsag.), longer sagittally than exsagittally where the anterior side passes from approximately straight to strongly concave backwards, more extended than L1 laterally, with lateral ends curving or projecting anterolaterally towards axial furrows at junction with posterolateral extremity of L1, slightly higher and more convex than L1 in lateral view, with posterior edge rather straight, bearing a stout and tall median occipital spine and two (rarely more) smaller spines adjacent laterally on each side (Figure 3.3). SO (occipital furrow) moderately deep and long (sag., exsag.), approximately straight sagittally more concave backwards laterally, where it is gently convex forwards deepening to become a long (exsag.) slot-like to commissural apodemal groove. L1 moderately narrow, shorter (sag.) than LO, with lateral part posterolaterally directed in dorsal view, anterior side concave and posterior side convex backwards, bearing mediumsized tubercles laterally (often with a more conspicuous large one), with a medial part (separated from lateral parts by a depression running exsagittally) which sometimes bears three big spiny tubercles disposed in a tight triangle. S1 of overall concave forwards shape, very weak sagittally, longer (exsag.) and deepest adaxially to became an apo- demal pit transversely elongated which is broadly subtriangular to lenticular in outline, then shallowing laterally to fade at junction with axial furrow. L2 longer sagittally than $\mathrm{L} 1$, approximately as long as the sagittal length of the occipital ring; with medial part separated from the lateral parts by an elongated and weak shallow depression anteromedially-posterolaterally oriented, bearing coarse to spinose tubercles (with one larger tubercle usually present); lateral part barely oriented backwards, longest (exsag.). S2 posterolaterally directed, starting adaxially as a deep commissural apodemal pit convex forwards (defining an exsagittal small convex projection coming from the most adaxial part L2 forward), then progressively weakening to become inconspicuous laterally at junction with axial furrow. L2 and L3 tending slightly to be fused and swollen. L3 with medial part approximately as long (sag.) as the L1, weakly convex in general, often bearing paired spines or strong spiny tubercles medially; lateral part increasing markedly in length and convexity (exsag.) laterally, almost twice as long as L2 distally, coarsely tuberculated bearing one (rarely more) largest tubercle laterally, projecting laterally, bending the axial furrow outwards. S3 forming an angle of about 60-70 degrees between each branch, long (exsag.) and deep, deepest adaxially, then rapidly broadening exsagittally to describe a conspicuous elliptical expansion (widely fossula-like) accompanied of an abrupt shallowing in front of (yet somewhat laterally to) the anterior extreme of palpebral lobe at junction with the axial furrow. Frontal lobe approximately rhombic in outline tending to be of symmetrical anterior and posterior aspects, comprising more than half sagittal length of glabella including the occipital ring, of width (tr.) comprising almost $45-50 \%$ cephalic width at level of occipital ring; showing a dorsal slightly more depressed area medially which tends to become a shallow and narrow (tr.) delicate furrow backwards. Tubercles of various sizes rather densely distributed on frontal lobe, very coarse in general and frequently tending to be elliptical in outline, coarser and moderately dense in two elongated zones anterolaterally-posteromedially oriented, coarsest and more densely disposed posteromedially, smaller and sparsely developed in the sagittal (along the delicately depressed median band), anterior and anterolateral zones, and particularly small and subdued on the entire periphery adjacent to the edge of frontal lobe. Eye situated with posterior edge opposite of $\mathrm{L} 1$, and anterior edge opposite of outer end of S3. Palpebral furrow deep and broad (tr.) strongly 
curved at midlength, with anterior section rather deeper than posterior section. Palpebral lobe elevated with respect to palpebral area, convex in transverse and exsagittal profile, slightly taller in the posterior part; palpebral rim weakly defined. Visual surface outline as a semicircle in dorsal view, inclined and slightly convex in frontal view; composed of 48-51? dorsoventral files, with a maximum of 16-17? lenses in some files (after CEGHUNC 10499). Anterior section of facial suture running subparallel to and just laterally of axial furrow near lateral corner of frontal lobe of glabella; posterior section as a convex curve forwards, crossing the genal field towards the inner edge of lateral border opposite posterior part of the eye, then deflected obliquely backwards to reach the cephalic margin in front of genal angle, with a shallow furrow-like depression associated anteriorly. Base of the eye limited by a moderately deep and short (tr.) surrounding furrow, associated with subparallel strong and rounded outer ridge.

Anterior portion of fixigena vestigial; interocular fixigena strongly reduced to a slopping and very narrow (tr.) continuation of the palpebral area towards axial furrow; posterior portion of fixigena adjacent to axial furrows as a very small and nearly triangular, more convex area; lateral portion of fixigena broadly (tr.) subtriangular, gently convex, bearing scarce subdued tubercles; continued towards the genal angle as a prominent and posterolaterally elongated ridge separating the posterior and lateral border furrows onto the base of the genal spine.

Posterior border moderately narrow (exsag.), ridge-like, slightly shorter than the lateral part of LO adjacent to axial furrow, then broadening markedly towards genal angle, bearing a number of posterodorsally directed small and coarse spines, the larger ones situated at fulcral level. Posterior border furrow deep and relatively broad (exsag.), limited anteriorly by the ridge of posterior portion of fixigena, starting as a broad (exsag.) furrow adjacent to axial furrow, then gently expanding laterally towards genal angle, then bending and narrowing rapidly backwards without meeting the lateral border furrow nor continuing along genal spine, posterior slope markedly steeper in the portion of the genal angle.

Librigenal field steeply sloping, moderately narrow (tr.), slightly narrower (tr.) anteriorly, gently convex in general, bearing scattered and subdued tubercles. Lateral border weakly concave, approximately as broad (tr.) as the median part of anterior border (sag.), bearing an epiborder furrow along the entire lateral margin of librigena. Epiborder furrow conspicuous, wide (tr.) and moderately deep, narrowing (tr.) and shallowing towards the genal spine where it continues as a furrow along the most external (lower) side. Lateral border furrow broad (tr.) and moderately shallow, weakly differentiated from librigenal field, and lateral border; slightly shallower and broader (tr.) on fixigena than on librigena, shallowest at genal angle and deflected outwards posteriorly onto base of genal spine. Base of genal spine bearing a longitudinal, posterolaterally directed ridge which is a continuation of the anterior edge of the posterior border furrow, and the effaced extension of lateral border furrow, herein abruptly interrupted. Genal spine flattened, relatively narrow (tr.), reaching at least the fourth thoracic segment (estimated because the spine is distally broken in the observed specimen CEGH-UNC 12738, Figure 4), bearing the continuation of the epiborder furrow along the outer side. Cephalic doublure incompletely known yet apparently composed of a slightly inflated anterior band and a more depressed posterior region.

Hypostome without material for description.

Thorax (Figure 4) composed of 11 segments. Wide (tr.) axis (about $55 \%$ of total segment width in anteriormost segments), with gentle dorsal convexity. Axial ring short (sag., exsag.), about $15 \%$ of total axial ring wide (tr.) medially, bearing several (typically four) large spiny tubercles dorsally, tending to be disposed in longitudinal rows along the thorax. Spiny tubercles defining two median files adjacent to the sagittal plane, continuing along pygidial axis, although more irregularly. Articulating half-ring separated from axial ring by a deep and moderately short (sag., exsag.) furrow. Lateral axial lobe $25 \%$ of total width (tr.) of axial ring, only weakly inflated and separated from median part of ring by means of a gentle depression. Axial furrow shallow and moderately narrow (tr.), slightly convex laterally along the thorax, with a small apodemal fossula posteriorly in each segment. Pleurae slightly oriented backwards with respect of the axis, with subhorizontal adaxial part wider (tr.) than abaxial part, this latter gradually inclined towards pleural tip so that the fulcrum is not sharply defined. Anterior pleural band ridge-like, much shorter (exsag.) than posterior pleural band adaxially, widening (exsag.) laterally towards the pleural tip, tallest at fulcrum, almost transversely directed adaxially then flexed backwards and narrowing (exsag.) beyond fulcrum, not bearing tubercles. Deep and wide (exsag.) pleural furrow of broad (exsag.), angular cross-section, starting as a fine 
line anteriorly at junction with axial furrow, running posterolaterally in a gentle curve, widening (exsag.) and deepening noticeably at fulcrum, then shallowing and narrowing to become an incised furrow most laterally, ending before the pleural tip. Posterior pleural band convex-topped, long (exsag.) about 2.5 times the length (exsag.) of anterior pleural band, longest at junction with axial furrows then narrowing (exsag.) laterally, barely flexed backwards and posterolaterally directed, bearing variably two or three (to four) large spiny tubercles of which the most adaxially located and that at fulcrum are the largest and tend to define longitudinal rows along the thorax towards pygidium. Distal part of pleurae acuminate. Articulating facet smooth and barely concave anterolaterally.

Pygidium (Figure 5), approximately as long (sag.) as wide (tr.), subtriangular in outline, with slightly convex lateral margins. Pygidial axis about $30 \%$ maximum pigidial width (tr.) anteriorly, diminishing to approximately $25 \%$ at level of seventh pygidial segment, then increasing again backwards (reaching almost $30 \%$ ) in the posteriormost segments. Total of 16-18 distinguishable axial rings, convex to barely flattened, bearing two longitudinal rows of subrounded projections defined by the more inflated portions of axial rings located immediately adjacent to the sagittal plane, which develop spines in some axial rings. Paired spines on axial rings distributed variably on axial rings 1,3 to 5,7 to 9,11 or 12 , and 16 ; most frequently present on rings 1, 3 and 4, 7 or 8,12 , and 16. Short (sag., exsag.) axial rings, tending to be more inflated laterally. Strongly marked axial segmentation except in the last few (2-3) effaced axial rings. Inter-ring furrows moderately long (sag., exsag.) and deep, deepest laterally where developed as elliptical to elongated (tr.) apodemal pits, without contacting the axial furrow. Elongated dorsal sagittal band of effaced segmentation present on the last 6-7 axial rings, which is progressively broader (tr.) and more conspicuous backwards, sometimes forming a subtle longitudinal furrow distally backwards. Terminal piece of effaced ornamentation continued as a long (sag.) and upturned mucro. Axial furrows broad (tr.), straight and moderately shallow, converging posteriorly gradually, showing delicate apodemal notches posteriorly in each segment. Pleural field moderately convex in posterior view, steeply inclined beyond fulcrum, with 12-13 (excluding the first anterior "half rib") strongly expressed pleural ribs sinuously (sigmoidally) bent backwards, abruptly deflected backwards at fulcrum (mainly the most anterior ones), exhibiting constrictions and enlargements; becoming more weakly defined, narrower (exsag.), straighter and more posteriorly directed gradually backwards, where trend to be subparallel to the axis. Anterior pleural band of slightly more height and width (exsag.) than posterior pleural band, narrowest (exsag.) at junction with axial furrow then broadening laterally, without tubercles. Posterior pleural band widest (exsag.) at junction with axial furrow then narrowing laterally, bearing one or two spinose tubercles or spines, diminishing slightly in height towards lateral margin. Tubercles or spines of posterior pleural band, irregularly disposed along pleural field, usually large and strong yet sometimes small or weakly defined in each segment, bending the interpleural furrow backwards so as to invade the anterior part of the adjacent anterior pleural band when they are very large. 13-14 pygidial pleural furrows well impressed, deep and wide (exsag.), slightly sinuous to sigmoidal, tending to be asymmetrical in cross section (exsag.) with anterior slope only subtly steeper than posterior one, abruptly deflected backwards and shallowing next to the lateral margin at fulcrum, gradually becoming narrower (exsag.), straighter and more posteriorly directed backwards. Interpleural furrows located barely more posteriorly than the midpoint (exsag.) of pleural ribs, as a delicately incised, fine (exsag.) and shallow line subparallel to the pleural rib, curving to surround backwards tubercles from the posterior pleural band. Neither a lateral border nor a lateral border furrow is conspicuously developed. Narrow and even pygidial doublure. Terrace lines could not be observed.

Remarks. The dalmanitine affinities of $D$. drevermanni have been commented on above in the discussion on the genus Dalmanitoides as well as similarities that support a close relationship between Fenestraspis and Dalmanitoides.

Fossiliferous nodules bearing $D$. drevermanni (Figure 3 and Figure 5 except pictures 11-14) in the type locality of Loma de los Piojos, occur sparsely in a more finely grained interval of greenish siltstones to mudstones of about $30 \mathrm{~m}$ thick, located approximately 110 to $140 \mathrm{~m}$ above the marker stratigraphic horizon of Keidel (Figure 2). According to the illustrations of Holloway and Carvalho (2009), these fossiliferous carbonate nodules and the preservation of trilobites contained, are identical to that of the holotype of $D$. drevermanni, so that we suspect that the type specimen studied by Thomas (1906) and collected by Hauthal was obtained from these same levels. This stratigraphic 
position corresponds to a probable early Emsian age, according to brachiopod data (Herrera, 1993, 1995a; Herrera and Bustos, 2001). However, D. drevermanni occurs (but infrequently) in wackes up to $40 \mathrm{~m}$ below Keidel's horizon (Figure 5, 11-13), as well as in overlying sandstone beds towards the upper part of the Talacasto Formation. Hence, a Pragian-Emsian biostratigraphic range is suggested for this species.

Strong tuberculation and spinosity seems be a typical character of $D$. drevermanni. Although the holotype appears to have a smooth posterior border (Holloway and Carvalho, 2009, p. 940), new materials demonstrate the presence of small spines there (Figure 3.9). Along the posteromedian part of the glabella, the holotype and additional material from the type levels exhibit strong tubercles or paired spines that on L1 are posteriorly disposed in a tight triangle (Figure 3.1, 3.3). However, this feature is considered of little diagnostic value for the species because it seems to exhibit continuous variation toward smaller and more irregularly distributed tubercles in some specimens, especially those coming from the La Chilca locality (Figure 6), which exhibit a number of diagnostic features of $D$. drevermanni (e.g., similar spinosity on the axial ring, posterior border and pygidium). Lack of spinose tubercules arranged in a triangle is also exhibited by the specimen CEGH-UNC 12738 (Figure 4.1, 4.2, 4.5) from the type locality of Loma de los Piojos, so that materials from La Chilca should not be considered a new species, nor a subspecies because of lack of geographic isolation (see Figure 1 for map). Nevertheless, as specimens from La Chilca section do not clearly preserve the anterior border, a character considered of diagnostic value, they are herein assigned to Dalmanitoides drevermanni with question (Figure 6 ), since more information is necessary to decide whether they represent a new taxon.

\section{Dalmanitoides boehmi (Knod, 1908)}

Figures 7-10

Material. Loma de los Piojos, Freiburg 2778, CORD-PZ 8609, 8611, CEGH-UNC 10496, 10502, 24315, 24331-24419, 24429.

Diagnosis of the species. Dalmanitoides with a wide (tr.) subrounded and flattened median process on anterior border, and two similar progressively smaller ones laterally, followed posteriorly by a long (exsag.) embayment of the lateral border, and two flattened and subrounded processes; large and very faint occipital tubercle; pygidium with subtle to rather coarse tubercles on posterior pleural bands irregularly distributed and variably expressed; stout but rapidly acuminate upturned mucro; small depressed area located sagitally between the end of the pygidial axis and a very coarse postaxial ridge.

Description. Because of the similarities with $D$. drevermanni, description of $D$. boehmi is given herein in comparative terms by highlighting differences. Only the hypostome is described in detail, since it is unknown in $D$. drevermanni.

Characters of $D$. boehmi, differing from $D$. drevermanni, includes: a cephalon whithout spines but coarse tubercles (Figure 7); subrounded and flattened median process without spiny projections on anterior border, two progressively smaller and rounded ones laterally, and a long (exsag.) embayment of the crenulated border more laterally, LO (occipital ring) bearing a large, rounded and slightly faint median occipital tubercle, visual surface composed of 46 dorsoventral files, with a maximum of 13 lenses in several files, lens formula approximated from the best preserved eyes (integrated from specimens CEGH-UNC 24394 and 24419), from anterior: 478910111212121212 ? 12? 12? 12? ? ? ? 1313131313131313131313 12121211101010101010109987 ? ? ?; anterior cephalic doublure composed medially of a slightly inflated ridge-like anterior band (excluding marginal processes) highest medially, and a more depressed posterior region, longer (sag.) medially; thoracic axial ring bearing tubercles tending to be disposed in longitudinal rows; posterior pleural band bearing variably two or three (to four) large spiny tubercles, pygidium (Figure 8) of dorsal aspect even and very finely granulated, with slightly convex lateral margins, pygidial axis including 16-17 axial rings bearing two longitudinal exsagittal rows defined by subrounded more inflated portions presents in several rings, which variably develop paired coarse tubercles in some more swollen axial rings (developed variably from conspicuous to more faint, and from regularly present in almost each ring to occurring irregularly, describing gaps of axial rings -commonly one to three- without conspicuous tubercles); depression between end of pygidial axis and the base of a coarse postaxial ridge; gently upturned mucro rapidly acuminate like a short spine whose base is slightly inflated; pygidial pleural field gently convex in posterior view.

Hypostome (Figure 9) with anterior part is incompletely known, so that wings and shoulder could not be observed. Anterior lobe of the middle body narrows backwards, moderately inflated, 


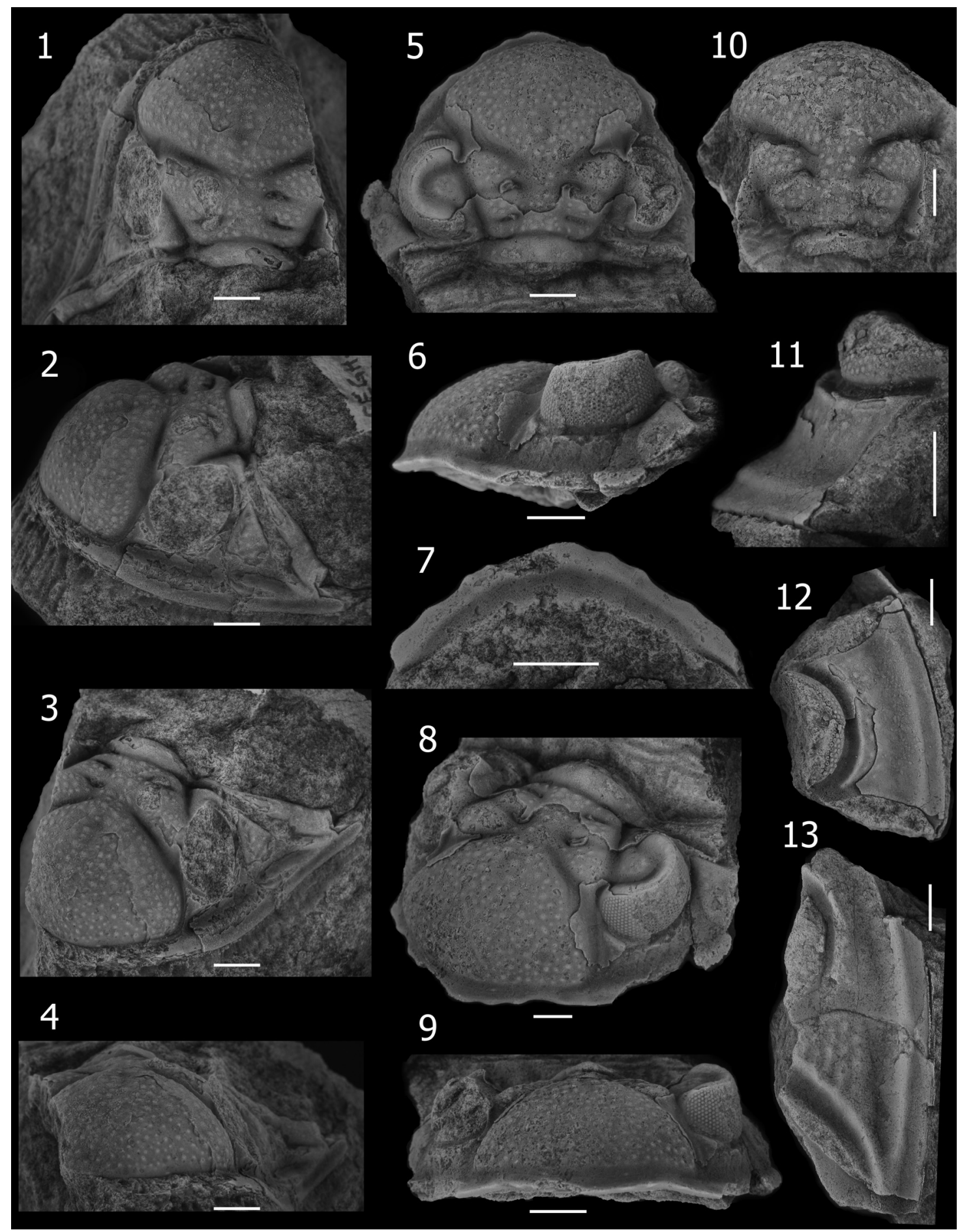

FIGURE 7. Cephala of Dalmanitoides boehmi (Knod, 1908). 1-4, specimen CEGH-UNC 24429, partial cephalon: 1, internal mould, dorsal view, note left S2 is effaced due to a malformation, 2, idem dorsolateral view, 3, idem anterodorsolateral view, 4, idem frontal view.5-9, specimen CEGH-UNC 24419, partial cephalon: 5, dorsal view, 6, idem lateral view, 7, detail of crenulated anterior margin, and anterior doublure, ventral view, 8, idem anterodorsolateral view, 9 , frontal view. 10, specimen CEGH-UNC 24315, partial cephalon, internal mould, dorsal view. 11-12, specimen CEGHUNC 24412, librigena showing the eye socle and the lateral doublure separated in a nearly sharp angle from the border (in cross section), 12 idem, dorsal view showing facial sutures. 13, specimen CEGH-UNC 24402, cheek showing the epiborder furrow, dorsal view. Loma de los Piojos Section, Talacasto Formation, Pragian levels under the guide horizon of Keidel (1921), San Juan Province, Argentina. Scale bar equals $5 \mathrm{~mm}$. 


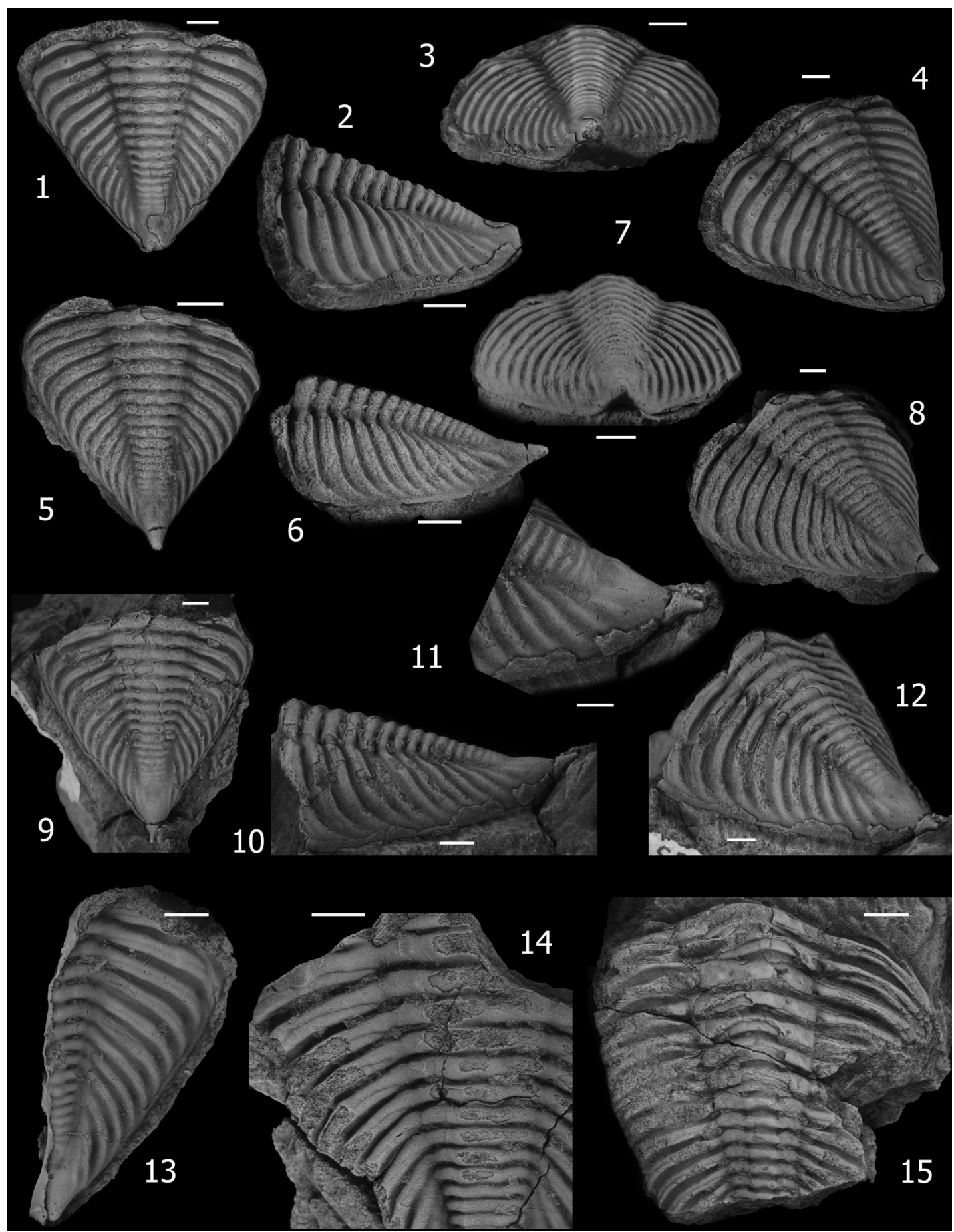

FIGURE 8. Pygidia of Dalmanitoides boehmi (Knod, 1908). 1-4, specimen CEGH-UNC 24379, internal mould, 1, dorsal view, 2, idem lateral view, 3, idem posterior view, 4, idem posterodorsolateral view. 5-8, specimen CEGH-UNC 24331, internal mould, 5, dorsal view, 6, idem lateral view, 7, posterior view, 8, posterodorsolateral view. 9-12, specimen CEGH-UNC 24374, internal mould, dorsal view. 10, lateral view, 11, detail of mucro, posterolateral view, 12, posterodorsolateral view. 13, specimen CEGH-UNC 24380, partial pygidium, latex cast. 14, specimen CEGH-UNC 24378, partial pygidium, dorsal view, note evenly granulated surface of the carapace and tubercules on posterior pleural bands invading following anterior pleural bands backwards. 15, specimen CEGH-UNC 24377, pygidium with some thoracic segments attached, dorsal view, note tubercles on thoracic axial rings and long (exsag.) thoracic pleural furrows. Loma de los Piojos Section, Talacasto Formation, Pragian levels of the guide horizon of Keidel (1921) and immediately underlying, San Juan Province, Argentina. Scale bar equals $=5 \mathrm{~mm}$. 


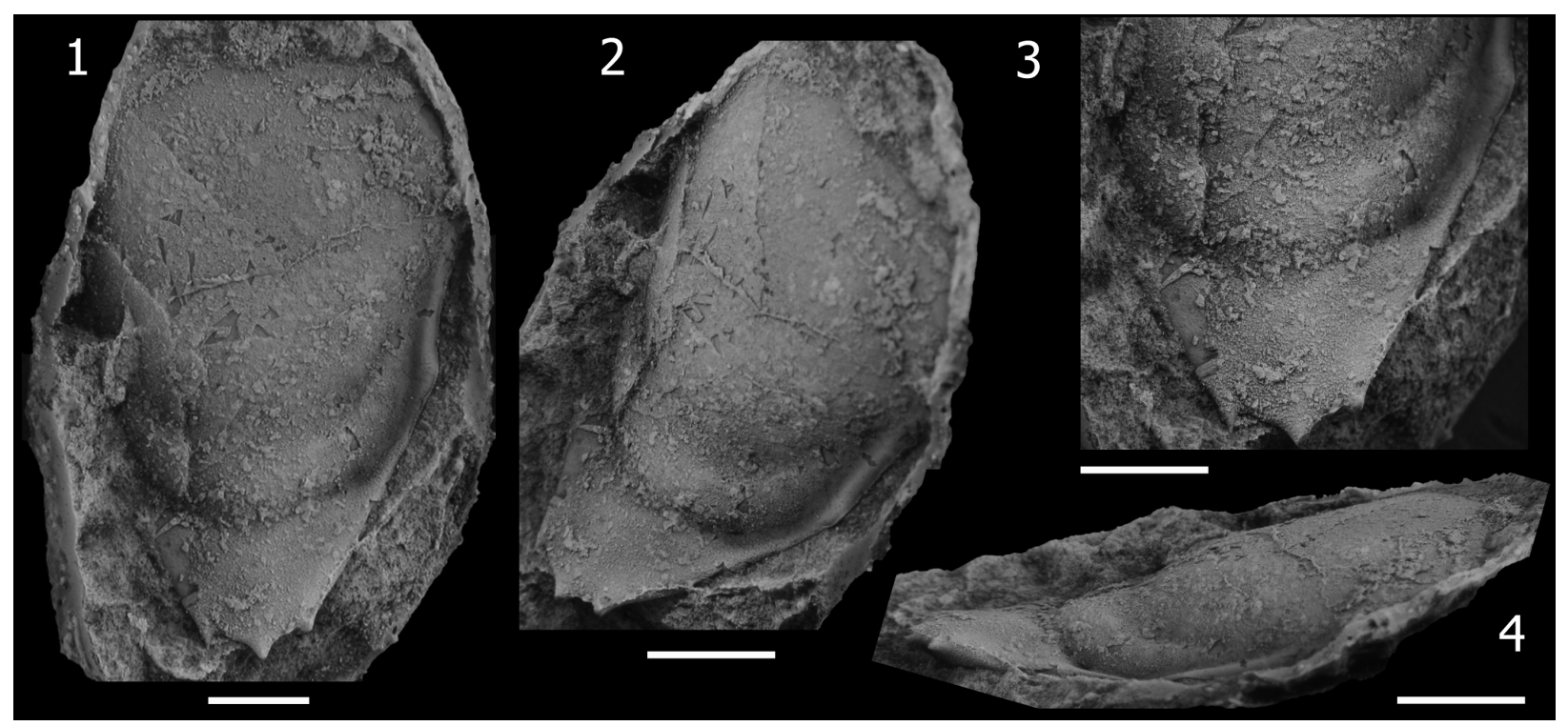

FIGURE 9. Hypostome of D. boehmi. 1-4, specimen CEGH-UNC 24377, 1, latex cast, ventral view, 2, anteroventrolateral view, 3, detail of denticles on posterior margin, 4, lateral view. Loma de los Piojos Section, Talacasto Formation, Pragian (early Emsian?) levels of the guide horizon of Keidel (1921), preserved in a nodule together with a pygidium, San Juan Province, Argentina. Scale bar equals $5 \mathrm{~mm}$.

bearing only subdued ornamentation. Posterior lobe of the middle body, moderately narrow (tr.) and slightly convex dorsally in lateral and posterior views. Middle furrow faint and shallowest anterolaterally near lateral border, deepening slightly and narrowing (tr.) up to a weak macula posteromedially, becoming very broad (sag., exsag.) and effaced medially. Lateral margin slightly concave anteriorly, converging gently backwards up to a distinct lateral projection, then straight and converging rapidly up the spiny posterolateral junction with posterior margin. Posterior margin convex in outline, with a conspicuous median spine directed backwards, and denticles or small spines at the posterolateral corners at junction with lateral margin. Lateral border, moderately inflated and narrow (tr.), widest in the lateral projection located slightly posterior to the middle furrow. Lateral furrow is progressively deeper and broader (tr.) backwards up to the posterolateral corner. Posterior border very long (sag., exsag), and approximately flat to slightly convex in posterior view. Posterior border furrow shallowing and narrowing (exsag.) from the anterolateral corner at junction with lateral border furrow.

Remarks. Although Thomas (1906, pp. 233, 242) said that Bodenbender collected the original material of $D$. boehmi, in the original label of the holotype specimen housed in Freiburg, Germany, it is written "Hauthal." This fact support the statement of Knod (1908, p. 567-568), who specified that the holotype specimen was collected by Hauthal at "west of Jáchal Valley," Jáchal, San Juan. This reference indicates that type material comes from outcrops somewhat to the west of the Loma de Los Piojos locality, (Figure 1). The species was described as having typically a couple of tubercles on each pygidial and thoracic axial ring, and based on this character it was subsequently reported from Bolivia (Kozłowski, 1923, p. 36, figure 2.1) and South Africa (Cooper, 1982, p. 55, figures 39.D, 40.A and B, 41.A, figure 42.C, figure 43). According to photographs of the holotype, however, these characters are not clearly observable. The holotype differs from the drawing published by Knod (1908, p. figure 21.1, see Figure 10) in having its left genal spine broken, the left anterior pleural side clean (without sediment), the dorsal axial part of the thorax eroded, the pygidium broken dorsally, and tubercles present on thoracic and pygidial pleurae (Figure 10). It seems that either the drawing published by Knod is "idealized" and/or the holotype suffered damage after it was drawn. In spite of the fact that missing data obscure the recognizing of diagnostic characters in the holotype, we assigned our material to $D$. boehmi because our specimens from Loma de los Piojos closely resemble it. The holotype seems to shows an occipital faint tubercule (a character not exhibited by any other Dalmanitoides species); the range of 

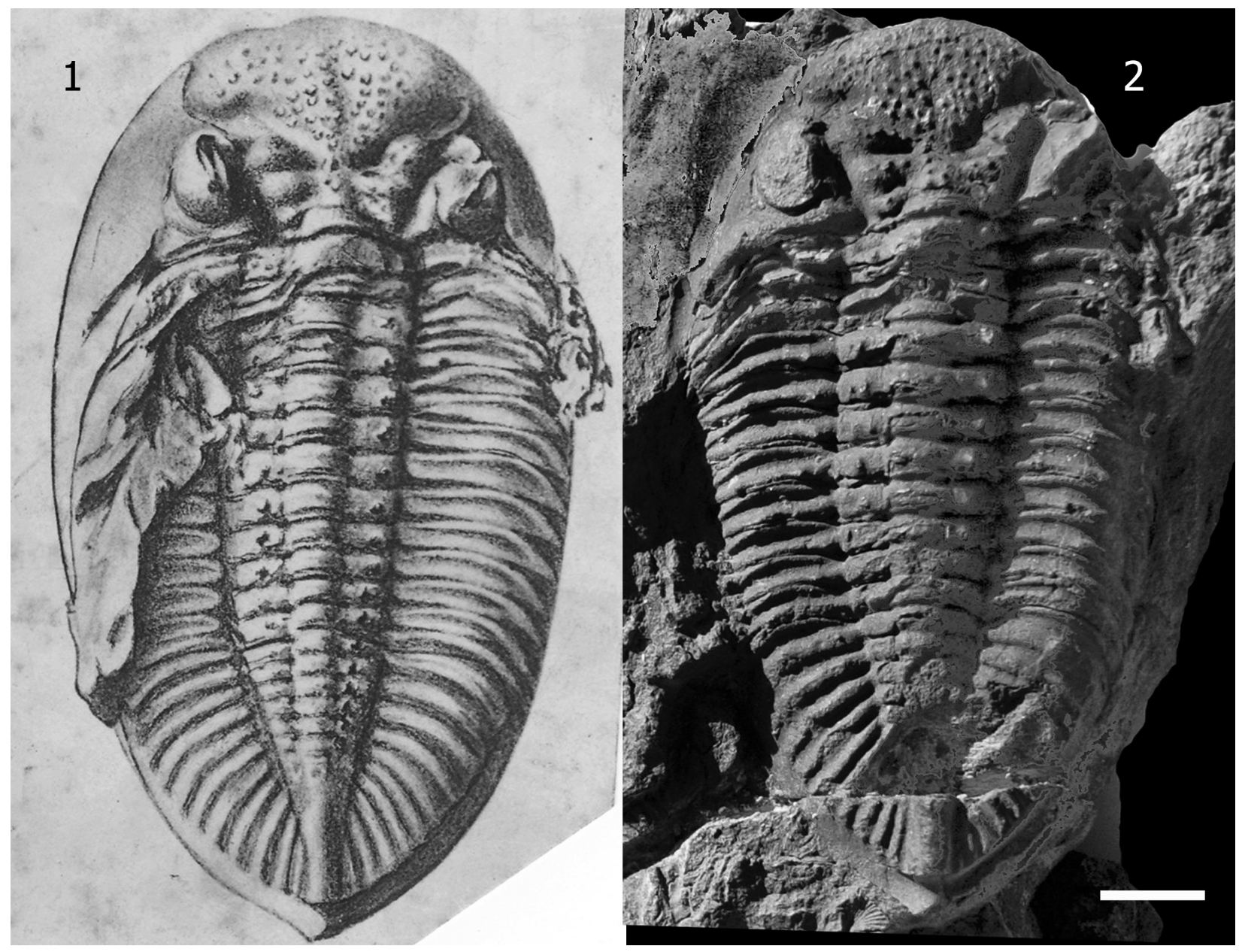

FIGURE 10. Dalmanitoides boehmi (Knod, 1908). 1, scanned copy of the original drawing published by Knod (1908, p. 567, figure 21.1). 2, the original holotype specimen collected by Hauthal from the Talacasto Formation, to the southwest of Jáchal, probably Pragian strata, to the west of Loma de los Piojos section, San Juan. Presently housed at University of Freiburg (Institut für Geowissenschaften-Geologie, repository number: 2778), Freiburg, Germany. Probably an internal mould, dorsal view. Note that the original fossil is either idealized in the drawing or suffered damage after it was published. Scale bar equals $5 \mathrm{~mm}$.

variability in the definition of longitudinal rows of tubercles in each ring along the pygidial axis include some specimens where this character is well-defined, and this species is the most abundant in all of Devonian outcrops near Jáchal, so that it is most probably the dalmanitid species that Hauthal found.

The stratigraphic position of $D$. boehmi in the Talacasto Formation corresponds to PragianEmsian levels (see Figure 2), and it is particularly abundant in micaceous sandy and carbonate nodules in the Keidel's (1921) guide horizon, as well as on bedding planes of sandy strata underlying it. This species exhibits a remarkable variation, mainly in the pygidial morphology and tuberculation. The dorsal convexity is somewhat variable in lateral view, and tubercles range from coarse to very faint, and from irregularly to regularly distributed in pairs along the pygidial axis (Figure 8). This regular tuberculation on the pygidial axis is evident in the original illustration of the holotype, but may have been damaged after its publication. Similar variation was reported by Edgecombe (1993, p. $165)$ for $D$. scutata and discussed in relation to sexual dimorphism. We observed a nearly continuous variation in these features of $D$. boehmi, and consequently we could not differentiate two or more discrete morphs.

D. boehmi most closely resembles $D$. scutata, yet this latter species differs in having an anterior border with a single round-margined anteromedian process, occipital ring without occipital 
node or tubercule, and a more strongly upturned mucro which is notably larger.

Eifelian specimens from the Voorstehoek Formation from South Africa were assigned to $D$. boe$h m i$ by Cooper (1982), based on the presence of paired axial tubercles on each pygidial axial ring. However, these specimens exhibit a large (spinose?) occipital tubercle and a bluntly rounded median process on the anterior border, which does not exhibits anterolateral crenulations. These features distinguish the South African specimens from $D$. boehmi, $D$. scutata, or $D$. drevermanni, but are shared with $D$. accola (Clarke, 1913, p. 101, figure 4.9-18) from the Ponta Grossa Formation, Paraná, Brazil.

As noted by Edgecombe (1993, p. 165), features separating South African specimens from $D$. accola include the regularity in the paired tubercles on the pygidial axial rings, as well as the number of dorsoventral lens files. These observations suggest that South African specimens belong to a different species based on the lack of tubercles on the thoracic axial rings, conspicuous regularity of paired tubercles on every pygidial axial ring, and a row of tubercles along the pygidial fulcral line, as well as the number of dorsoventral lens files (up to 40 in D. accola, and near 30-32 in the South African material). Nevertheless, only a few pygidia from the South African form clearly display the distribution of pygidial axial pairs of tubercles, and consequently we agree with Cooper (1982, p. 59) that the range of variability in this character is not sufficiently documented. Furthermore, taking into account data from Clarke (1913, p. 103) and additional material of $D$. accola that we examined (Figure 11), paired pygidial tubercles in this species seem be present on more rings and are more irregularly distributed than has been reported (e.g., Edgecombe, 1993, p. 165). Hence, considering this character is highly variable in other Dalmanitoides species, the South African specimens could be conspecific with the Brazilian $D$. accola as Cooper conjectured (1982, p. 61). Differences could be interpreted being of subspecies level, as Clarke (1913) suggested. Hence, we leave the South African species in open nomenclature as Dalmanitoides sp. A.

Dalmanitoides sp. A from South Africa, lacks tubercles on the axial rings, a feature also noted in the Bolivian specimen reported by Kozłowski (1923, p. 36, figure 2.1) and referred to Dalmanites boehmi var. boliviensis, so that it appears to be conspecific according to Cooper (1982). However, this assignment is tentative since we have not revised the Bolivian material, and characters such as the anterior border have not been observed from illustrations . Due to this fact, we neither provide an opinion on the synonymy of the non-tuberculate Bolivian species Dalmanites patacamayensis Kozłowski, 1923, a similar form which appears to belong to Dalmanitoides (Kozłowski, 1923, p. 36, figure 2.2).

\section{REMARKS ON PALEOBIOGEOGRAPHY AND PHYLOGENY}

Devonian records of Dalmanitoides suggest a diversification involving at least five species during the Early-Middle Devonian. This evidence suggests no migrations but rather isolation and speciation of a stock of widely distributed Dalmanitine trilobites already present by the earliest Devonian, in Malvinokaffric basins. This pattern is consistent with that recognized for other Malvinokaffric trilobite groups (Eldredge and Ormiston, 1979; Abe and Lieberman, 2009; Rustán and Vaccari, 2010).

Nevertheless, the close similarities between Dalmanitoides and the slightly earlier genus Roncellia from Gaspe, Appalachian region of Canada (Eastern Americas Paleobiogeographic Realm), suggests a southerly dispersal from northern paleolatitudes during the Early Devonian. Roncellia is considered sister taxon of Dalmanitoides, and the ancestral area of the clade should be located in boreal regions, the area of most ancient stratigraphic records. To date, the earliest stratigraphic record of Dalmanitoides is Pragian, so that taking into account the slightly older (Lochkovian?) record of Roncellia (Lespérance and Bourque, 1971), and derived characters of Dalmanitoides (i.e., long and curvy genal spines and tuberculated ornamentation), migrations from the South to the North seem to be less probable.

As was discussed by Holloway and Carvalho (2010), a similar case occurs with respect to paleobiogeographical implications of the synphoriine genus Chacomurus Braniša and Vaněk, 1973, from the Pragian-Emsian of the lower member of the Belén Formation from Bolivia, which is hardly differentiated from the North American Eifelian sister genus Coronura Hall and Clarke, 1888.

In contrast with dalmanitines, synphoriines were overall considered of strongest affinities with the Eastern Americas Paleobiogeographical Realm, according to Carvalho and Fonseca (2007). Hence, these authors proposed migrations from the Appalachian region by the Eifelian as explanation of the synphoriine origins in Malvinokaffric basins, based on the presence of Amazonaspis 

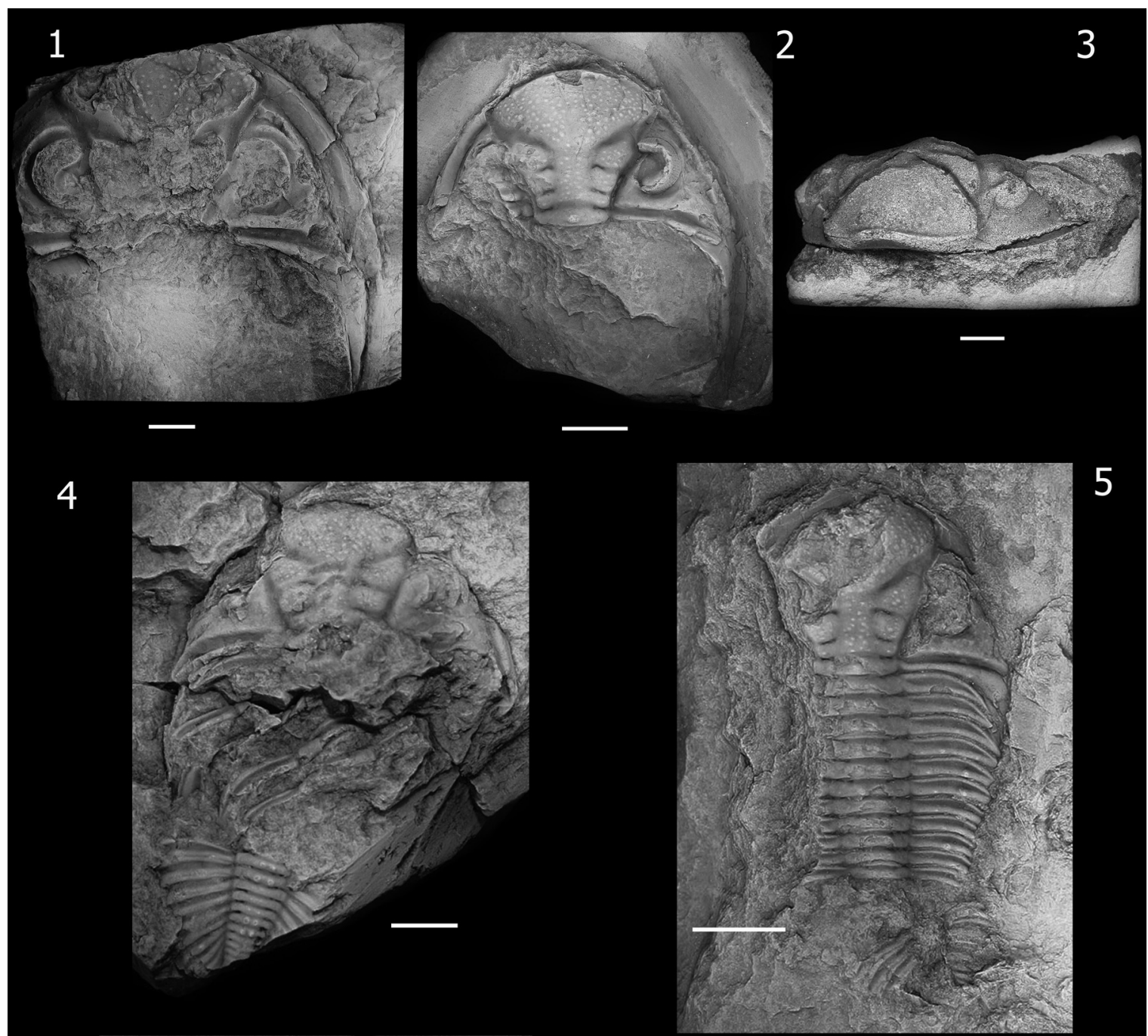

5

6
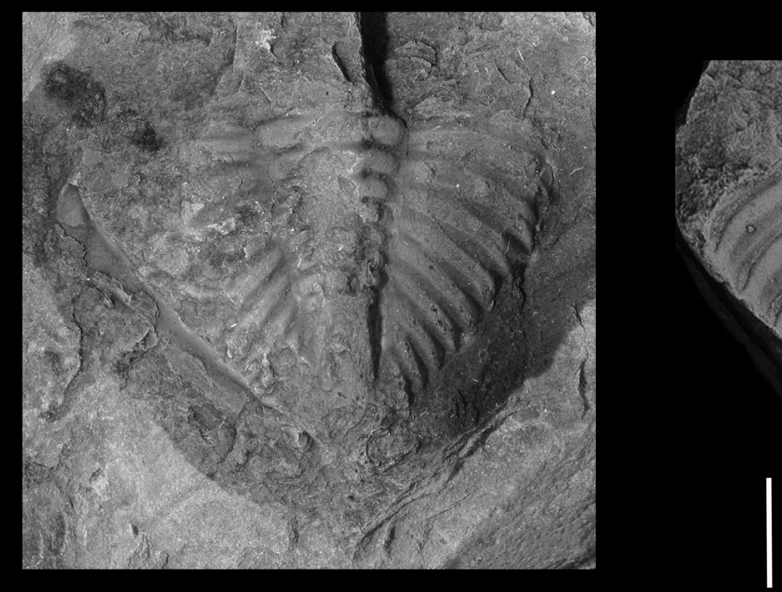

7

FIGURE 11. Dalmanitoides accola (Clarke, 1913). 1, specimen NYSM 12069 , cephalon, dorsal view, note lack of crenulation on anterior border anterolaterally. 2, specimen NYSM 12072, cephalon, internal mould, dorsal view. 3, specimen NYSM 12077, cephalon, anterolateral view, note the rounded median projection of the anterior border. 4, specimen NYSM 17262 , skeletal associated parts (moult ensemble?), dorsal view, note the irregular distribution of coarse to spinose tubercles on pygidial axial rings. 5, specimen NYSM 17304, nearly articulated specimen, dorsal view. 6, specimen NYSM 17466, pygidium, internal mould, dorsal view. 7, specimen NYSM 17467, external mould of pygidium, dorsal view. Lower Devonian, Ponta Grossa Formation, Paraná, Brazil. Scale bar equals 5 mm. 
maecurua (Clarke, 1890), from the Middle Devonian Maecurú Formation, Amazonas Basin, Pará, Brazil. Subsequently, the presence of Chacomurus in Bolivia (Holloway and Carvalho, 2010) confirmed the presence of synphoriines in South America by the Early Devonian, suggesting an older dispersal event.

Although Dalmanitoides was interpreted in this synphoriine framework, in accordance with Chacomurus's data, its reassignment to the dalmanitines suggest that the phylo-geographic history of the taxon could not be the same than synphoriines. A similar conclusion could be extended to Fenestraspis, because of the questioned synphoriine affinities according comparisons with Dalmanitoides given earlier in the text. Additional, Late Silurian-Lochkovian dalmanitine data from Argentina would be of particular interest in these issues, which we consider open to further discussions.

\section{ACKNOWLEDGMENTS}

R. Haude and B. Waisfeld have facilitated the study of material from Loma de los Piojos collected by them. D. Balseiro, R. Foglia, and A. Rydczewski have collaborated invaluably in the field works of the authors. The curator in charge at University of Freiburg, Ursula Leppig, successfully localized the holotype of $D$. boehmi in the repository of that institution, and kindly took photographs. E. Landing and F. Mannolini contributed by taking nice photographs of $D$. accola specimens housed at New York State Museum, Albany, U.S.A. and specifying repository numbers. G. Edgecombe and B. Chatterton revised an earlier version of the manuscript, contributing with fruitful comments. Two anonymous reviewers spent precious time in providing detailed suggestions in order to improve this work. Financial support for this study was provided by CONICET and ANPCyT (Agencia Nacional de Promoción Científica y Tecnológica) PICT-200601272, grant to Claudia Rubinstein.

\section{REFERENCES}

Abe, F.R. and Lieberman, B.S. 2009. The nature of evolutionary radiations: a case study involving Devonian trilobites. Evolutionary Biology, 36:225-234.

Astini, A.R. 1991. Sedimentología de la Formación Talacasto: plataforma fangosa del Devónico precordillerano, provincia de San Juan. Revista de la Asociación Geológica Argentina, 44:277-294.

Baldis, B.A. 1975. El Devónico Inferior en la Precordillera Central. Parte I: Estratigrafía. Revista de la Asociación Geológica Argentina, 30:53-83.
Bracaccini, O.I. 1949. El perfil de Tambolar. Revista de la Asociación Geológica Argentina, 4:165-179.

Braniša, A.L. and Vaněk, J. 1973. Several new trilobite genera of the superfamily Dalmanitacea Vogdes, 1890 in the Devonian of Bolivia. Vestník Ustredního Ústavu Geologického, 48:97-101.

Bustos, U.D. 1996. Modelo sedimentario alternativo para el Devónico de la Precordillera central sanjuanina: Formación Punta Negra. Revista de la Asociación Argentina de Sedimentología, 3:17-30.

Bustos, U.D. and Astini, A.R. 1997. Formación Punta Negra: análisis secuencial y evolución de la Cuenca Devónica Precordillerana. Revista de la Asociación Argentina de Sedimentología, 4:97-111.

Campbell, K.S.W. 1977. Trilobites of the Haragan, Bois d'Arc and Frisco Formations (Early Devonian) Arbuckle Mountains Region, Oklahoma. Oklahoma Geological Survey Bulletin, 123:1-227.

Carvalho, M.G. and Fonseca, V.M.M.D. 2007. The trilobite 'Dalmanites' maecurua Clarke, 1890 (Middle Devonian, Amazon Basin, Brazil) and the new genus Amazonaspis (Synphoriidae). American Museum Novitates, 3591:1-14.

Clarke, J.M. 1913. Fosseis devonianos do Paraná. Monografias Serviço Geologico e Mineralogico do Brasil, 1:1-353.

Cooper, M.R. 1982. A revision of the Devonian (EmsianEifelian) Trilobita from the Bokkeveld Group of South Africa. Annals of the South African Museum, 89:1174.

Delo, D.M. 1935. A revision of the phacopid trilobites. Journal of Paleontology, 9:402-420.

Edgecombe, G.D. 1993. A revision of the Devonian dalmanitid trilobite Gamonedaspis. Revista Técnica de Yacimientos Petrolíferos Fiscales Bolivianos, 1314:161-166.

Edgecombe G.D., Vaccari N.E., and Waisfeld, B.G. 1994. Lower Devonian calmoniid trilobites from the Argentine Precordillera: new taxa of the Bouleia group, and remarks on the tempo of calmoniid radiation. Geological Magazine, 131:449-464.

Eldredge, N. and Ormiston, L. 1979. Biogeography of Silurian and Devonian Trilobites of the Malvinokaffric Realm p. 147-167. In Gray, J. and Boucot, H.J. (eds.), Historical Biogeography, Plate Tectonics, and the changing Environment. Oregon State University Press, Corvallis.

Hall, J.C. and Clarke, J.M. 1888. Descriptions of the trilobites and other Crustaceae of the Oriskany, Upper Helderberg, Hamilton, Portage, Chemung and Catskill groups. New York State Geological Survey, Natural history of New York, Palaeontology 7:1-236.

Herrera, Z.A. 1993. Nuevas precisiones sobre la edad de la Formación Talacasto (Precordillera Argentina) en base a su fauna de braquiópodos. Actas del 12do Congreso Geológico Argentino y 2do Congreso de Exploración de Hidrocarburos, 2: 289-295. 
Herrera, Z.A. 1995a. The first notanopliid brachiopod from the South American Devonian sequence. Geobios, 28:337-342.

Herrera, Z.A. 1995b. The Lower Devonian chonetoidean brachiopods from the Argentine Precordillera, p. 101147. In Racheboeuf, P. (ed.), Four contributions to the study of chonetoidean brachiopods. Documents des Laboratories de Géologie Lyon. Centre des Sciences de la Terre, Université Claude-BernardLyon I, Lyon.

Herrera, Z.A. and Bustos, U.D. 2001. Braquiópodos devónicos de la Formación Punta Negra, en el perfil del Río de las Chacritas, Precordillera Argentina. Ameghiniana, 38:367-374.

Holloway, D. 1981. Silurian dalmanitacean trilobites from North America, and the subfamilies Dalmanitinae and Synphoriinae. Palaeontology, 24:695-731.

Holloway, D. and Carvalho, M.G. 2009. The extraordinary trilobite Fenestraspis (Dalmanitidae, Synphoriinae) from the Lower Devonian of Bolivia. Palaeontology, 52:933-949.

Holloway, D. and Carvalho, M.G. 2010. The trilobite Chacomurus (Dalmanitidae, Synphorinae) from the Lower Devonian of Bolivia. Memoirs of the Association of Australasian Palaeontologists, 39:71-83.

Keidel, J. 1921. Observaciones geológicas en la Precordillera de San Juan y Mendoza. Anales del Ministerio de Agricultura, Sección Geología, Mineralogía y Minería, 15:7-102.

Knod, R. 1908. Devonische Faunen Boliviens, p. 493600. In Steinmann, G. (ed.), Beiträge zur Geologie und Paläontologie von Südamerika. Neues Jahrbuch für Mineralogie, Geologie und Paläontologie 25. E. Schweizerbart, Stuttgart.

Kozłowski, R. 1923. Faune devonienne de Bolivie. Annales de Paleontologie, 12:1-112.

Lespérance, P. 1975. Stratigraphy and paleontology of the Synphoriidae (Lower and Middle Devonian dalmanitacean trilobites). Journal of Paleontology, 49:91-137.
Lespérance, P. and Bourque, P.A. 1971. The Synphoriinae: an evolutionary pattern of Lower and Middle Devonian trilobites. Journal of Paleontology, 45:182208.

Padula, E., Rolleri, E., Mingramm, A.R., Criado Roqué, P., Flores, M.A., and Baldis, B.A. 1967. Devonian of Argentina, p. 165-199. In Oswald, D. (ed.), Proceedings of the International Symposium on the Devonian System, 2. Canadian Society of Petroleum Geologists, Calgary.

Racheboeuf, P.R. and Herrera, Z.A. 1994. Über einige neue silurische und devonische Chonetaceen-Arten (Brachiopoda), und Reklassifizierung anderer Arten (On some new malvinokaffric Silurian and Devonian chonetacean brachiopods and reclassification of others). Neues Jahrbuch für Geologie und Paläontologie, Monateshefte, 9:541-560.

Rustán, J.J. and Vaccari, N.E. 2010. The aulacopleurid trilobite Maurotarion Alberti, 1969 in the SilurianDevonian of Argentina: systematic, phylogenetic and paleobiogeographic significance. Journal of Paleontology, 84:1082-1098.

Thomas, I. 1906. Neue Beiträge zur Kenntnis der Devonischen Faunen Argentiniens. Zeitschrift der Deutschen geologischen Gesellschaft, 57: 233-290.

Vaccari, N.E., Waisfeld, B.G., and Edgecombe, G.D. 1994. Calmoniid Trilobites of the Lower Devonian Scaphiocoelia zone in the Argentine Precordillera. Geobios, 27:591-608.

Vogdes, A.W. 1890. A bibliography of Paleozoic Crustacea from 1698 to 1889 including a list of North American species and a systematic arrangement of genera. United States Geological Survey Bulletin, 63:1-177.

Waisfeld, B.G., Edgecombe, G.D., and Vaccari, N.E. 1994. Tormesiscus, a new blind calmoniid trilobite from the Lower Devonian, Argentine Precordillera. Geologica et Palaeontologica, 28:27- 43. 